\title{
BioéthiqueOnline
}

\section{Medical Assistance in Dying in Canada: An Ethical Analysis of Conscientious and Religious Objections}

\section{Timothy Christie, John Sloan, Dylan Dahlgren et Fred Koning}

Volume 5, 2016

URI : https://id.erudit.org/iderudit/1044272ar

DOI : https://doi.org/10.7202/1044272ar

Aller au sommaire du numéro

Éditeur(s)

BioéthiqueOnline

ISSN

1923-2799 (numérique)

Découvrir la revue

Citer cet article

Christie, T., Sloan, J., Dahlgren, D. \& Koning, F. (2016). Medical Assistance in Dying in Canada: An Ethical Analysis of Conscientious and Religious Objections. BioéthiqueOnline, 5. https://doi.org/10.7202/1044272ar
Résumé de l'article

Contexte : La Cour Suprême du Canada (CSC) a décidé que le gouvernement fédéral a pour obligation d'éliminer les dispositions du Code criminel du Canada qui interdisent l'aide médicale à mourir (AMAM). La CSC a stipulé que les médecins individuels ne seront pas tenus de fournir l'AMAM s'ils ont une objection religieuse ou de conscience. Par conséquent, la réponse législative en attente devra équilibrer les droits des patients avec les droits des médecins, d'autres professionnels de la santé, et les institutions exprimant des objections. Objective : L'objectif de cet article est d'évaluer de façon critique, dans le contexte Canadien, la probité morale des objections personnelles ou institutionnelles à l'AMAM qui sont soit pour des raisons religieuses ou de conscience.

Méthodes : L'éthique déontologique et la doctrine de la double finalité. Résultats : L'objecteur religieux ou de conscience a des devoirs conflictuels, i.e., un devoir de respecter le "droit à la vie" (section 7 de la Charte) et un devoir de respecter les principes de ses croyances religieuses ou de conscience (protégés par la section 2 de la Charte).

Conclusion : La discussion des objections religieuses ou de conscience à l'AMAM n'a pas pris en considération d'une façon explicite les devoirs concurrents de l'objecteur de conscience. Elle a mis l'accent sur le fait que l'objection de conscience existe et a ignoré la question normative de savoir si le devoir de respecter sa propre conscience ou sa religion l'emporte sur le devoir de respecter le droit à la vie du patient.
Droits d'auteur @ C T Christie, J Sloan, D Dahlgren et F Koning, 2016

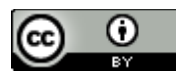

Ce document est protégé par la loi sur le droit d'auteur. L’utilisation des services d’Érudit (y compris la reproduction) est assujettie à sa politique d'utilisation que vous pouvez consulter en ligne. 


\title{
Medical Assistance in Dying in Canada: An Ethical Analysis of Conscientious and Religious Objections
}

\author{
ARTICLE (RÉVISION PAR LES PAIRS / PEER-REVIEWED) \\ Timothy Christie ${ }^{1,2,3}$, John Sloan ${ }^{4}$, Dylan Dahlgren $^{5}$, Fred Koning ${ }^{6}$ \\ Reçu/Received: 1 Apr $2016 \quad$ Publié/Published: 17 Aug 2016 \\ Éditeurs/Editors: Charles Dupras \\ Évaluateurs externes/Peer-Reviewers: Udo Schuklenk \& Anonymous
}

2016 T Christie, J Sloan, D Dahlgren, F Koning, Creative Commons Attribution 4.0 International License

\section{Résumé}

Contexte : La Cour Suprême du Canada (CSC) a décidé que le gouvernement fédéral a pour obligation d'éliminer les dispositions du Code criminel du Canada qui interdisent l'aide médicale à mourir (AMAM). La CSC a stipulé que les médecins individuels ne seront pas tenus de fournir l'AMAM s'ils ont une objection religieuse ou de conscience. Par conséquent, la réponse législative en attente devra équilibrer les droits des patients avec les droits des médecins, d'autres professionnels de la santé, et les institutions exprimant des objections.

Objective : L'objectif de cet article est d'évaluer de façon critique, dans le contexte Canadien, la probité morale des objections personnelles ou institutionnelles à l'AMAM qui sont soit pour des raisons religieuses ou de conscience.

Méthodes: L'éthique déontologique et la doctrine de la double finalité

Résultats : L'objecteur religieux ou de conscience a des devoirs conflictuels, i.e., un devoir de respecter le "droit à la vie" (section 7 de la Charte) et un devoir de respecter les principes de ses croyances religieuses ou de conscience (protégés par la section 2 de la Charte).

Conclusion : La discussion des objections religieuses ou de conscience à l'AMAM n'a pas pris en considération d'une façon explicite les devoirs concurrents de l'objecteur de conscience. Elle a mis l'accent sur le fait que l'objection de conscience existe et a ignoré la question normative de savoir si le devoir de respecter sa propre conscience ou sa religion l'emporte sur le devoir de respecter le droit à la vie du patient.

\section{Mots clés}

aide médicale à mourir, objection de conscience, devoirs conflictuels, éthique déontologique

\section{Abstract}

Background: The Supreme Court of Canada (SCC) has ruled that the federal government is required to remove the provisions of the Criminal Code of Canada that prohibit medical assistance in dying (MAID). The SCC has stipulated that individual physicians will not be required to provide MAID should they have a religious or conscientious objection. Therefore, the pending legislative response will have to balance the rights of the patients with the rights of physicians, other health care professionals, and objecting institutions.

Objective: The objective of this paper is to critically assess, within the Canadian context, the moral probity of individual or institutional objections to MAID that are for either religious or conscientious reasons.

Methods: Deontological ethics and the Doctrine of Double Effect.

Results: The religious or conscientious objector has conflicting duties, i.e., a duty to respect the "right to life" (section 7 of the Charter) and a duty to respect the tenets of his or her religious or conscientious beliefs (protected by section 2 of the Charter).

Conclusion: The discussion of religious or conscientious objections to MAID has not explicitly considered the competing duties of the conscientious objector. It has focussed on the fact that a conscientious objection exists and has ignored the normative question of whether the duty to respect one's conscience or religion supersedes the duty to respect the patient's right to life.

\section{Keywords}

medical assistance in dying, conscientious objection, conflicting duties, deontological ethics

\section{Responsabilités des évaluateurs externes}

Les évaluations des examinateurs externes sont prises en considération de façon sérieuse par les éditeurs et les auteurs dans la préparation des manuscrits pour publication. Toutefois, être nommé comme examinateur n'indique pas nécessairement l'approbation de ce manuscrit. Les éditeurs de BioéthiqueOnline assument la responsabilité entière de l'acceptation finale et la publication d'un article.

\section{Peer-reviewer responsibilities}

Reviewer evaluations are given serious consideration by the editors and authors in the preparation of manuscripts for publication. Nonetheless, being named as a reviewer does not necessarily denote approval of a manuscript; the editors of BioéthiqueOnline take full responsibility for final acceptance and publication of an article. 
Affiliations des auteurs / Author Affiliations

${ }^{1}$ Horizon Health Network, Saint John Regional Hospital, Saint John, Canada

${ }^{2}$ Department of Bioethics, Faculty of Medicine, Dalhousie University, Halifax, Canada

${ }^{3}$ Department of Humanities and Languages, University of New Brunswick, Saint John, Canada

${ }^{4}$ Faculty of Medicine, University of British Colombia, Vancouver, Canada

${ }^{5}$ Department of History, University of New Brunswick, Fredericton, Canada

${ }^{6}$ Quorum Review Institutional Review Board, Seattle, USA

\section{Correspondance / Correspondence}

Timothy Christie, Timothy.Christie@HorizonNB.ca

\section{Remerciements}

Nous aimerions remercier le Rev. Dr. Marc Smith pour son regard critique et attentif sur ce manuscrit. Ses commentaires pertinents ont permis de renforcer ce manuscrit.

\section{Conflit d'intérêts}

Aucun déclaré

\section{Acknowledgements}

We would like to acknowledge the Rev. Dr. Marc Smith for his critical yet careful review of this manuscript. His insightful review forced us to strengthen this manuscript.

Conflicts of Interest

None to declare

\section{Background}

In 1972, attempted suicide was decriminalized in Canada and since then the courts have consistently stated that patients have the right to refuse life-sustaining medical treatment. However, until Carter v. Canada (Attorney General) in 2012, they have been careful to distinguish the legal acts of withdrawing or withholding life-sustaining medical treatment from the illegal acts of medical assistance in dying (MAID), physician assisted suicide, medically assisted dying, and active euthanasia which are terms used to describe the situation where a physician (or health care professional) helps a patient end their own life or actively ends the patient's life for compassionate reasons [1].

In 1993, the late Sue Rodriguez challenged sections 241(b) and 14 of the Criminal Code of Canada (CCC) which make it illegal to counsel, aid, or abet a person to commit suicide and forbids individuals from consenting to death [2]. Rodriguez argued that sections 7, 12, and 15 of the Canadian Charter of Rights and Freedoms (the Charter) were violated by this prohibition [3].

1. The Canadian Charter of Rights and Freedoms guarantees the rights and freedoms set out in it subject only to such reasonable limits prescribed by law as can be demonstrably justified in a free and democratic society.

7. Everyone has the right to life, liberty and security of the person and the right not to be deprived thereof except in accordance with the principles of fundamental justice.

12. Everyone has the right not to be subjected to any cruel and unusual treatment or punishment.

15. (1) Every individual is equal before and under the law and has the right to the equal protection and equal benefit of the law without discrimination and, in particular, without discrimination based on race, national or ethnic origin, colour, religion, sex, age or mental or physical disability [3].

The crucial argument was the Section 7 challenge. The Supreme Court of Canada (SCC) concluded that prohibiting MAID meant that Sue Rodriguez might have to commit suicide prematurely if there was no guarantee that a qualified medical practitioner would be authorized to help her die at a time of her choosing. Although the SCC agreed that Section 7 was violated, they concluded that this infringement was saved by Section 1 , in other words, this violation was "demonstrably justified in a free and democratic society." 
At that time the SCC was concerned with the practical issue of protecting vulnerable individuals from being subtly coerced into requesting MAID. In 1993, no jurisdiction had successfully implemented safeguards that could protect vulnerable patients so the SCC ruled that the only protection was a complete prohibition on MAID. Between 1993 and 2012, nine jurisdictions in the world had implemented MAID programs with seemingly effective safeguards. Subsequently, on February 6 , 2015 the SCC unanimously declared that the sections of the CCC that prohibited MAID were invalid. Specifically, they stated that grievously ill patients have a legal right to assistance with the termination of their life.

Section 241(b) and s. 14 of the Criminal Code unjustifiably infringe s. 7 of the Charter and are of no force or effect to the extent that they prohibit physician-assisted death for a competent adult person who (1) clearly consents to the termination of life and (2) has a grievous irremediable medical condition (including an illness, disease or disability) that causes enduring suffering that is intolerable to the individual in the circumstances of his or her condition [1].

The SCC suspended the declaration of invalidity for 12-months and then granted the federal government an additional four-month extension, which expired on June 6, 2016.

In this decision, the SCC was careful to state that although individual patients' have a right to MAID, this does not mean that any individual physician has a duty to provide MAID. We quote the decision in Carter: "Nothing in this declaration would compel physicians to provide assistance in dying. The Charter rights of patients and physicians will need to be reconciled in any legislative and regulatory response to this judgment." [1] The SCC did not articulate the specific Charter rights that will have to be reconciled; however, it is reasonable to expect that Section 2 and Section 7 could conflict in certain circumstances.

Of particular relevance to this discussion is Wesley Hohfeld's meticulous analysis of legal rights, where he explains the difference between "claim rights" and "privilege rights" [4]. Within this context, the right to MAID is technically called a "claim right," which has two important properties. The first is that claim rights are passive, in other words, the individual does not have to do anything to activate the right; every person who meets the eligibility criteria will possess this right simply by virtue of the legal structures of the society in which they live. In addition, a necessary condition of a claim right is that it impose an active "duty" on someone else. This means that the patient's passive claim right to MAID places an active duty on the government (which typically delegates healthcare responsibilities to the provinces or health authorities) to provide this procedure when requested.

The right to freedom of conscience and religion is an active privilege right. It is active in the sense that one has to act according his or her conscience or defer to a religion in order to exercise this right. The state, however, does not determine the content of these rights. The individual citizen is free to choose the content of these beliefs. Therefore, the "structure or form" of the right to freedom of conscience or religion is that it is a "legal active privilege right" but the content of the right is idiosyncratic and determined by the individual. That is, it is the individual who determines the tenets of his or her conscience and the individual decides which religion, if any, to subscribe. Furthermore, the privilege right to a conscientious or religious objection could extend from individual physicians to the nursing profession, to the other allied health professions, and to entire facilities like Catholic hospitals. One of the clearest statements voicing a religious objection to MAID comes from the Catholic Health Alliance of Canada.

Catholic teaching holds that the deliberate taking of a human life goes against the dignity of the human person. It violates the foundational principle of right reason and that all human life is sacred. Neither providing nor participating in assisted suicide or euthanasia aligns with the principles and values of Catholic healthcare and are not to occur in Catholic healthcare institutions [5]. 
The Catholic Health Alliance is not alone in its concerns with MAID. The Canadian Medical Association, which represents over 83,000 members, made a submission to Parliament's Joint Committee on Medical Assistance in Dying in which they "strongly recommended" that a physician's freedom of conscience be recognized in any federal legislation [6]. Likewise, many nursing associations advocate that individual nurses must have the option to refuse to cooperate with MAID for conscientious reasons [7]. Finally, the Provincial-Territorial Expert Advisory Group on Physician Assisted Dying explained in detail that individual physicians are entitled to a conscientious objection to MAID [8].

A conscientious objection can arise when Section 2 rights conflict with Section 7 rights, i.e., in circumstances where the idiosyncratic content of a Section 2 protected belief (either religious or conscientious) comes into conflict with the provision of MAID (protected by Section 7). For example, some religions might claim that ending life for compassionate reasons is contrary to their beliefs and therefore, believers of that faith cannot participate in MAID. From the Section 7 perspective, however, the SCC concluded that denying patients the right to MAID might compel patients to end their life while able bodied which could cause premature death and is thus a direct violation of their Section 7 rights. Specifically, the SCC said the following:

Insofar as they prohibit physician-assisted dying for competent adults who seek such assistance as a result of a grievous and irremediable medical condition that causes enduring and intolerable suffering, ss. $241(b)$ and 14 of the Criminal Code deprive these adults of their right to life, liberty and security of the person under of the Charter. The right to life is engaged where the law or state action imposes death or an increased risk of death on a person, either directly or indirectly. Here, the prohibition deprives some individuals of life, as it has the effect of forcing some individuals to take their own lives prematurely, for fear that they would be incapable of doing so when they reached the point where suffering was intolerable [1].

We shall argue that although advocates have articulated a desire for legislative provisions that respect conscientious objections to MAID, they have not provided any normative reasons to justify this recommendation. The fact that a conscientious objection exists (which is a descriptive claim) does not automatically justify the normative conclusion that it should be respected. We will argue that the existence of a conscientious objection to MAID necessarily entails the existence of a duties conflict. The conflict will be between the duty to respect life and the duty to respect the tenets of one's conscience or religion. The arguments proffered by advocates overlook this important ethical dilemma and the ethical analysis is circumvented by pleas for a referral system that allows conscientious objectors to respect the tenets of their conscience by making provisions for patients to be referred to individuals or facilities that do not hold such objections.

\section{Objective/ Methods}

The objective of this paper is to critically assess the moral probity of individual or institutional objections to MAID for religious or conscientious reasons (here after referred to as "conscientious objection"). It is important to note that this paper is not a challenge to religious doctrines or moral convictions. We note the Catholic Health Alliance position as an example of a well-articulated religious objection to MAID. However, our analysis applies to both conscientious as well as religious objections. It is important to note that we are focussing on the unique Canadian debate that has resulted from the Carter decision (2012 and then the SCC 2016 decision). Moreover, we have restricted our discussion to MAID only; we have not examined the role of conscientious objection in healthcare in general nor have we considered the role of conscientious objections to other issues like abortion, stem cell research, or participation in war. 
Our goal is to conduct an inquiry into the logical and moral underpinnings of conscientious objections to MAID within the Canadian context. We will explain the religious and philosophical foundations of this objection and articulate the trade-offs associated with prioritizing one moral duty over another. Deontological ethics, particularly the Doctrine of Double Effect, will be used as a framework to analyze the nature of conscientious objections to MAID. We realize that there are other major approaches to moral theory that are not addressed in this essay, e.g., utilitarianism and virtue ethics. We think that deontological reasoning is implicit in a conscientious objection and it is for this reason that we have chosen to analyze this moral issue from the perspective of deontological ethics.

\section{Results}

\section{Deontological Ethics}

The essence of deontological ethics is that moral worth is determined by examining the motivation/intentions of the person for his or her conduct. To be moral, one must act according to the proper motivation, with the right intentions, out of a sense of duty, and out of respect for the moral law. According to the moral law, certain actions are intrinsically right and others are intrinsically wrong. The moral agent's duty is to act out of respect for the moral law for its own sake (i.e., intrinsic value), not because of the consequences the action will produce (i.e., instrumental value). A very important feature of deontological ethics is a resounding rejection of consequences when determining the moral worth of an action. According to a deontologist, morality demands obeying the moral law and doing one's duty regardless of the consequences. According to this theory, one would not be justified in doing something that is intrinsically bad even if it will produce good consequences.

Philosophers and theologians often provide differing arguments for where the moral law comes from. Divine Command Theory (DCT), for example, is a deontological theory, which asserts that the moral law is derived from God's will. For example, a famous book contains the following famous quotations: "Thou shalt not kill" and "Love thy neighbour as thyself [9]." According to DCT these commands are duties and constitute a moral law.

The most important secular approach to deontological ethics is the work of Immanuel Kant [10]. Kant argued that the source of the moral law is not a 'divine will' but rather it is accessible by all rational beings if they think carefully enough and use the rules of logic. For Kant, the Categorical Imperative is the instrument used to determine if any particular action is moral or not. The Categorical Imperative states that one should be able to universalize the intention/motivation for the action without contradiction (i.e., make it a universal law); a different formulation providing the same insight is to treat humanity as an end in itself and not as a means only.

As an illustration of the Categorical Imperative, consider Sections 2 and 7 of the Charter. The Categorical Imperative asks if one could will, as a universal law, that everyone everywhere has the rights to life, liberty, security of the person and the right to freedom of religion and conscience. Since these could be willed as a universal law they would pass the first and second formulations of the Categorical Imperative. Providing these rights to individuals would be an example of respecting individuals as ends in themselves and not treating them as a means only.

\section{Doctrine of Double Effect (DDE)}

One of the most important contributions of St. Thomas Aquinas is his refinement of the doctrine of double effect, which was originally presented as an argument for why an act of self-defence, which might result in the assailant's death, is morally justified [11]. The DDE states that nothing prevents one_act from having two effects. There is an important difference between: 1) causing harm as a sideeffect of pursuing a morally acceptable goal, and 2) causing harm as a means of achieving a morally good goal. 
Consider the example of titrating morphine for the treatment of refractory pain in a terminally ill cancer patient. There might come a point during treatment where the dose of morphine could pose a risk of overdose to the patient. In other words, in an attempt to treat pain there could be a risk that the patient fatally overdoses. In this situation, the DDE would say that the intention was to treat pain, which is a morally good action and the bad outcome of death would be indirectly voluntary. Therefore, this would not be an example of killing the patient. Similar arguments could be made for withholding or withdrawing life-sustaining treatment. The argument here is that the patient is simply allowed to die, not that the patient is killed.

MAID would not pass this test. In MAID, the patient either ends her life herself, or her life is ended by a healthcare professional for compassionate reasons. Hence, the "act" of killing is considered "bad" and it is this "bad" action that is used to achieve the desirable consequence of compassion. Deontological ethics rejects any consideration of consequences when determining the moral worth of an action.

\section{Conflicting Deontological Duties}

A major problem for deontological ethics is when two or more duties conflict. For example, the Charter guarantees two possibly conflicting rights in regards to MAID, Section 2 and Section 7. Divine Command Theory and Kantian Deontology have no mechanism for resolving conflicting duties. Other deontological approaches, such as that developed by Paul Ramsey, a moral theologian, or W.D. Ross, a philosopher, provide procedures for resolving conflicting duties. However, these alternative approaches pay a high price for this advantage; they are forced to make the concession that moral duties are not absolute; sometimes one moral duty would be more important than another. It is not clear that those holding a conscientious objection to MAID would accept that their conscientious objection is not an absolute duty. Ironically, a consequence of this uncompromising stance may be that the conscientious objector has two conflicting moral duties.

\section{Discussion}

An important feature of ethical reasoning is to make explicit absolute moral duties that are mutually exclusive through consideration of all the values, rights, and duties involved in an ethical decision. From our analysis it appears that there are at least two conflicting duties for any conscientious objector to MAID: 1) the duty to respect the patient's right to life, liberty and security of the person, and 2) the freedom of religion or conscience. The moral difficulty is that simply asserting a conscientious objection to MAID does not automatically justify the normative conclusion that this conscientious objection should be respected. The assertion of a conscientious objection is simply the acknowledgement that there are conflicting duties.

The duties conflict is not only between the patient and the conscientious objector, but it exists within the persona of the conscientious objector him or herself. It exists within, given that the conscientious objector has a duty to respect the patient's right to life. Inherent in a conscientious objection is the concession that "but for" the conscientious objection a duty would exist to respect the patient's right to life (i.e., a duty to participate in MAID). A claim to conscientious objection is essentially an appeal to be exempted from what would otherwise be a duty. In this case, the conflicting duties arise because the 'privilege right' to follow the tenets of a particular religion or of an individual's conscience might forbid ending life for compassionate reasons, which would necessarily prohibit MAID.

If we are correct in concluding that the conscientious objector has two conflicting and mutually exclusive duties, within herself, then simply articulating that a person holds a religious or conscientious objection (i.e., simply making a descriptive statement) does not in any way address the normative question of which duty should be respected. In other words, for a normative conclusion to be ethically justified, some type of normative process is required. 
Our position is different than that of other commentators like Schuklenk and Smalling, who argue that physicians are not ethically permitted to hold a conscientious objection in the first place [12]. They argue that since physicians enter the profession voluntarily, that services like abortion or MAID are legal, and that since physicians hold a monopoly on these services, they are not ethically justified in prioritizing their private beliefs at the expense of patient rights. Our argument is less ambitious. We do not argue that physicians are not justified in denying services because of a conscientious objection. Rather, we suggest that the conscientious objector has at least two conflicting duties and that prioritizing the duty to respect one's conscience over the duty to respect life, without any form of normative justification is the antithesis of ethical reasoning.

Our final consideration is that we are aware that instead of addressing the ethical issue of whether conscientious objections to MAID are ethically justified, there is a desire to develop a practical solution that attempts to produce a "win-win" situation for everyone. For example, virtually every discussion of conscientious objection to MAID focusses on a referral system. Such a system is described by the Provincial-Territorial Expert Advisory Group on Physician Assisted Dying:

The Carter ruling underscored the need to reconcile the interests of patients and providers. As we explain in this report, health care providers have the freedom to object to the provision of physician assisted dying for reasons of conscience, but they are required to provide information about all end-of life options, including physicianassisted dying. Conscientiously objecting health care providers are also required to either provide a referral, a direct transfer of care to another health care provider, or to contact and transfer the patient's records through a third party, agency or service which would have a duty to ensure the safe and timely transfer of care of the patient to a nonobjecting provider.

Health institutions, including regional health authorities and other institutional providers (e.g., hospitals, hospices and long-term care facilities) are critical enablers of effective and equitable access to physician assisted dying. Non-faith-based institutions should have an obligation to provide physician-assisted dying and faith-based institutions should have an obligation to either provide physician-assisted dying or make arrangements for a safe and timely transfer of the patient to a non-objecting institution. Regardless of how the process unfolds, we believe that there must be continuity of care for the patient [8].

The goal of this type of referral system is to solve the problem of competing duties; the conscientious objector can refuse to provide MAID and the patient can still receive the service. We fully acknowledge that this proposed solution is a bona fide attempt to respect the rights of all stakeholders. However, we note two inherent problems with this solution. 1) Making a referral could be seen as a form of cooperation with MAID and thus still could be problematic for the conscientious objector. 2) Most healthcare facilities in Canada are in an overcapacity situation, where occupancy exceeds $100 \%$ and thus transferring patients is frequently difficult.

First, consider this very strong, anti-euthanasia statement published in the Vatican Council II's document, "Pastoral Constitution on the Church in the Modern World."

It is necessary to state firmly once more that nothing and no one can in any way permit the killing of an innocent human being, whether a fetus or an embryo, an infant or an adult, an old person, or one suffering from an incurable disease, or a person who is dying. Furthermore, no one is permitted to ask for this act of killing, either for himself or herself or for another person entrusted to his or her care, nor can he or she consent to it, either explicitly or implicitly, nor can any authority legitimately recommend or permit such an action. For it is a question of the violation of the divine law, an offense against the dignity of the human person, a crime against life, and an attack on humanity [13]. 
A plausible interpretation of this statement could be that according to this belief system, the patient is not justified in requesting MAID, the physician and institution are not permitted to provide MAID, and it is also possible that merely making a referral for MAID might violate the beliefs of this religion (or at least the individual's or institution's interpretations of the beliefs of this religion). Notwithstanding the fact that the pending Canadian legislation likely will include the requirement to make a referral, conscientious objectors might simply find another practical way of getting around this responsibility.

Consider the following hypothetical example, and for the sake of discussion pretend that it is occurring after the new legislation is proclaimed in June 2016.

Ms. $E$ is 88 years old and suffers from mild Alzheimer's disease and has severe constant pain from spinal stenosis (constriction of nerves in her spine) and a previous herpes zoster (shingles) infection. She also has chronic lung disease, Parkinson's disease, and mild heart failure. The pain has been treated by a pain specialist but all the options to control both pains have failed. It is Ms. E's determination that she has lived a good and satisfying life, her pain is terrible, and her life expectancy short, therefore, she wishes to end her life with MAID.

Before arrangements can be made for MAID through her family physician, she falls at home one night fracturing her hip, and is taken by ambulance to the closest hospital, which happens to be Roman Catholic. Her hip is repaired, but new atrial fibrillation (a heart rhythm disturbance) has to be treated and in the course of this, other heart problems and possible cancer in the abdomen are discovered and must be evaluated. Weeks pass. In constant pain, Ms. E looks forward to eventually returning home but hospital professionals determine that she is not safe to live alone. By this time she has lost a lot of strength, flexibility, and self-confidence; and a hospital psychiatrist states that she is no longer capable of making her own decisions.

Her family physician tells her hospital doctor of Ms. E's previous mentally competent decision to have MAID because of untreatable pain, but the GP is told this is counter to the principles of the institution and since she is no longer competent, MAID cannot occur.

With the patient population that will be eligible for MAID, timeliness is going to be a relevant consideration because inherent in many conditions is the eventual loss of competency. Individuals or institutions that have a conscientious or religious objection to MAID might simply delay the initiation of transfers until it is too late.

Secondly, the evidence to date suggests that the acute care system might not have sufficient flexibility to transfer patients from one facility to another with any degree timeliness or reliability. The number of patients seeking MAID is expected to be relatively low; however, the number of qualified healthcare professionals willing to provide MAID, at least in its nascence, is also expected to be low. Compound this with the current accessibility issues like waitlists for specialists, surgeries, as well as the Alternate Level of Care issue and one has good reason to suspect that a referral process may look good on paper but there might be significant logistical barriers that limit timely access. For example, Ms. E would have to be transferred (presumably by ambulance) from her current location in the Roman Catholic hospital to a non-objecting facility. That facility would have to provide a suitable space, which might include a private room, as well as the staff and medications necessary to provide MAID. Furthermore, most provincial governments and health authorities are developing fairly complex processes that each patient receiving MAID will have to go through, e.g., multiple assessments, signing multiple documents, mandatory waiting period, psychosocial counselling, etc. 


\section{Limitations}

Our analysis is limited to the SCC Carter decision, which provides a nuanced interpretation of section 7 and MAID. As we have emphasized, the SCC found that prohibiting MAID unjustifiably infringes section 7 of the Charter. If this point is not conceded, then our analysis is moot. The conscientious objector is presumably against terminating life; therefore, he or she finds him or herself in a position of conflict if it is conceded that denying individuals' access to MAID could force them to end their lives early. However, one could logically argue that not only should MAID be illegal but the prohibition of suicide should be put back into the CCC. In this case, it is possible to simply state that the SCC was wrong in its interpretation of the Charter and MAID. Nevertheless, we have attempted to analyze this debate within the framework set out by the SCC; other commentators might not be so inclined.

\section{Conclusions}

We cannot overstate the bona fide nature of conscientious objections or the importance of these beliefs to individuals. These are strongly held, sincere, and genuine beliefs that, at least in some instances, are supported by thousands of years of tradition. Of an equal bona fide nature, however, is the almost universal right to life, liberty and security of the person. This right is so important that virtually every constitutional democracy exalts it as a pillar of their society. Given this ethical dilemma, professional organizations like the Catholic Health Association, the Canadian Medical Association, and the Federal, Provincial, Territorial, Expert Group on Physician Assisted Dying should complete their work. To date, they have simply articulated one side of the argument, deriving a normative conclusion without any normative justification. Furthermore, they have proposed a pragmatic solution that attempts to generate a "win-win" situation for everyone. Unfortunately, the result of this pragmatism is that the ethical dilemma remains unanalyzed.

\section{List of References}

1. Carter v. Canada (Attorney General), 2015 SCC 5, [2015] 1 S.C.R. 331

2. Rodriguez v. British Columbia (Attorney General), [1993] 3 S.C.R. 519

3. Canadian Charter of Rights and Freedoms, Part I of the Constitution Act, 1982, being Schedule B to the Canada Act 1982 (UK), 1982, c 11.

4. Hohfeld, WN. Some fundamental legal conceptions as applied in judicial reasoning, 23 Yale Law Journal 16 (1913).

5. Catholic Health Alliance of Canada. Medical Assistance in Dying - Alliance Briefing. September 2015.

6. Canadian Medical Association. CMA's Submission to the Special Joint Committee on Physician-Assisted Dying. January 27, 2016.

7. Christie, T. Nursing practice and assisted death. INFO Nursing 46(1), 27 (2015)

8. Provincial-Territorial Expert Advisory Group on Physician Assisted Dying. Final Report. November 2015.

9. Exodus 20:1-21, Deuteronomy 5:1-23, Ten Commandments, New Bible Dictionary, Second Edition, Tyndale House. 1982: pp. 1174-1175

10. Immanuel Kant. Fundamental Principles of the Metaphysic of Morals. Project Gutenberg. $1785 / 2004$.

11. Aquinas, Thomas $\left(13^{\text {th }}\right.$ c). Summa Theologica II-II, Q. 64, art. 7, "Of Killing", in On Law, Morality, and Politics, William P. Baumgarth and Richard J. Regan, S.J. (eds.), Indianapolis/Cambridge: Hackett Publishing Co., 1988, pp. 226-7.

12. Schuklenk $U$ and Smalling R. Why medical professionals have no moral claim to conscientious objection accommodation in liberal democracies. Journal of Medical

Ethics doi:10.1136/medethics-2016-103560

13. Sacred Congregation for the Doctrine of Faith. Declaration on Euthanasia (Jura et bona, 5 May, 1980), section II. 